\title{
Effect Differences of Fermented and Non-Fermented Red Dragon Fruit Peel on Blood Glucose Levels of Hypercholestrolemic Wistar Rats
}

\author{
Natalia Desy Putriningtyas ${ }^{1}$, Mardiana $^{2}$, Siti Wahyuningsih ${ }^{3}$

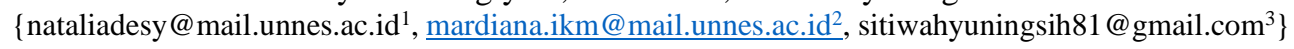

Universitas Negeri Semarang, Semarang, Indonesia ${ }^{1,2}$

Universitas Respati Yogyakarta, Yogyakarta, Indonesia ${ }^{3}$

\begin{abstract}
Hypercholesterolemia is associated with oxidative stress. Antioxidant activity can found in red dragon fruit peel. This study aims to analyse the effect of fermented and non-fermented red dragon fruit peel on blood glucose levels of hypercholesterolemic Wistar rats. Twenty plasma Wistar rats were divided into four groups: P1 (negative); P2 (hypercholesterolemic group, not received any treatment); P3 (red dragon fruit peel yogurt $1.8 \mathrm{~g} / 200 \mathrm{~g}$ BW); P4 (red dragon fruit peel marmalade $0.94 \mathrm{~g} / 200 \mathrm{~g}$ BW). Hypercholesterolemic condition was induced using cholesterol and cholic acid powder. Blood glucose levels were measured using GOD-PAP. The paired t-test and One-Way ANOVA was used to determine the mean differences in blood glucose level before and after intervention. The reduction in blood glucose levels in P1; P2; P3 and P4 were 0.28 $\pm 0.55 \mathrm{mg} / \mathrm{dL} ; 2.66 \pm 1.92 \mathrm{mg} / \mathrm{dL} ;-24.60 \pm 5.77 \mathrm{mg} / \mathrm{dL} ;-18.66 \pm 2.23 \mathrm{mg} / \mathrm{dL}$, respectively. We concluded that red dragon fruit peel yogurt lowers blood glucose more than dragon fruit peel marmalade.
\end{abstract}

Keywords: Blood glucose level, marmalade, red dragon fruit peel, wistar, yogurt.

\section{Introduction}

Metabolic syndrome is a group of conditions consisting of more than three different cardiovascular risk factors including abdominal obesity, pathological conditions in blood pressure concentrations, blood glucose levels, triglycerides and serum HDL. Metabolic syndrome is associated with type 2 diabetes mellitus and heart disease [1]. The aetiology of metabolic syndrome is unknown although modifiable risk factors such as physical activity, smoking habits, alcohol consumption accompanied by dietary habits including dairy foods, western diet and food based dietary guidelines also influence the occurrence of metabolic syndrome. Metabolic syndrome can advance to cardiovascular disorders [2].

Intake of vegetables, fruit, lentils, herbs is a source of flavonoids which represent the polyphenols group. Previous studies indicate that several classes of flavonoids are important in supporting heart health and preventing type 2 diabetes mellitus. The sub-classification of flavonoids is divided into flavonols, flavones, flavanones, 3-ols flavan, isoflavones and anthocyanins [3]. Red dragon fruit is gaining attention worldwide because it has economic and even health benefits. Red dragon fruit is a source of phytochemicals such as flavonoids, anthocyanins and terpenoids. A study by Song et al. shows that the phytochemicals act as freeradical scavengers because they have antioxidant properties that are related to protective actions 
in overcoming inflammation, atherosclerosis and hyperlipidaemia [4]. Red dragon fruit peel is the part that is used in our study. The selection of dragon fruit peel as the main ingredient is due to its higher antioxidant content compared to the flesh, and the use of red dragon fruit peel has not been massively explored [5]. The antioxidant capacity of red dragon fruit peel is highly related to the total phenols content.

This study used two kinds of red dragon fruit peel: fermented and non-fermented. The fermented fruit peel was made into yoghurt, while the non-fermented was in the form of marmalade.

Yogurt is a source of probiotics. Probiotics are substances or organisms that maintain the balance of the intestinal microbiota. Red dragon fruit peel yogurt in this study used lactic acid bacteria Lactobacillus bulgaricus and Streptococcus thermophillus. The mechanism of action of probiotics includes triggering mucin secretion, immunomodulators in the intestine related to lymphoid tissue and increasing immunosuppressive and decreasing proinflammatory mediators [6]. A study conducted by Mardiana using processed red dragon fruit peel into yogurt showed that the flavonoid content in red dragon fruit peel yogurt could be further developed into a functional drink [7]. Another processed form used in this study is red dragon fruit peel marmalade. The red dragon fruit peel marmalade in this study was produced by mixing red dragon fruit peel with sucrose which had a gel-like texture. The definition of marmalade based on SNI (Indonesian National Standard) is a semi-wet food product made from a mixture of orange juice, chopped orange peel and sugar with or without permitted food additives [8].

Our study used marmalade and yogurt derived from red dragon fruit peel which are also low-glycaemic food sources to control blood glucose levels.

\section{Methods}

This study used stored hypercholesterolemic Wistar rat plasma. Hypercholesterolemic conditioning in Wistar rats using $1 \%$ cholesterol powder and $0.5 \%$ cholate acid manufactured by Sigma Aldrich, Japan. This study received a recommendation from the Health Ethics Committee, Universitas Negeri Semarang (permission number: 140 / KEPK / EC / 2019).

The chosen dosages were according to a study conducted by Putriningtyas [9] and Mardiana [7]. Red dragon fruit peel yogurt is a fermented product derived from full cream milk, red dragon fruit peel, sucrose and lactic acid bacteria with a ratio of 1: $25 \%: 10 \%: 10 \%$. The lactic acid bacteria used in the process of making red dragon fruit peel yogurt were Lactobacillus bulgaricus and Streptococcus thermophillus with a ratio of 5\% each.

The red dragon fruit peel marmalade began by crushing some of the red dragon fruit peel using a blender, then in the cooking process, some pieces of dragon fruit peel and sucrose were added. Red dragon fruit peel marmalade has a ratio of $1: 30 \%: 10 \%$ for the soft peel : red dragon fruit peel : sucrose.

The sample size was calculated using the WHO formula in pre-clinical research; based on the calculation, we needed 20 samples. This study consisted of 4 groups $(n=5)$. The stored Wistar rat plasma in this study was grouped into the negative/ not hypercholesterolemic rats and did not receive treatment $(\mathrm{P} 1)$; hypercholesterolemic group and did not receive treatment (P2); hypercholesterolemic; receiving yogurt $1.8 \mathrm{~g} / \mathrm{kg} \mathrm{BW} / \mathrm{d}(\mathrm{P} 3)$; hypercholesterolemic; receiving marmalade $0.94 \mathrm{~g} / \mathrm{kg} \mathrm{BW} / \mathrm{d}(\mathrm{P} 4)$. 
The Glucose Oxidase Phenol 4-Aminophenazone (GOD-PAP) was used to measure blood glucose levels. Blood glucose levels was measured at the Laboratory of the Centre for Food and Nutrition Studies, Universitas Gadjah Mada, Yogyakarta.

Statistical analysis used the means \pm standard deviation (SD) in each group. The data was normally distributed so the differences in body weight and blood glucose levels before and after treatment were determined using the paired t-test. The differences between groups used oneway analysis of variance (ANOVA). The level of significance used was $\mathrm{p}<0.05$.

\section{Results and discussion}

Red dragon fruit is known as Red pitaya (Hylocereus polyrhizus). Dragon fruit is a group of fruit plants that come from the Cactacea family. Red dragon fruit has an attractive shape with a purple-red peel colour with delicate, juicy flesh with black seeds scattered on the flesh. Dragon fruit cultivation is almost spread throughout Asia even though it originally came from the American continent. The popularity of red dragon fruit is increasing because it is believed to have health benefits such as reducing the incidence of dyslipidaemia and hyperglycaemia [10]. Red dragon fruit is not only consumed directly but also through preparations such as drinks, jams and even candy. As the results of processing red dragon fruit flesh, a lot of waste products are produced in the form of red dragon fruit peel. The weight of the peel reaches $22 \%$ of the total weight of the red dragon fruit. The soft part of the red dragon fruit peel reaches $92.7 \%$ and is composed of total soluble solids, protein, ash, fat and carbohydrate groups. The carbohydrates in this fruit are pectin, glucose, maltose and fructose [11].

The different structures of flavonoids have an effect on their bioavailability and bioactivity. During the digestion process, flavonoids are further metabolized in the ileum and duodenum before ending up in the colon. Flavonoids are fermented by the intestinal microbiota in the colon. The intestinal microbiota plays a role as the metabolic reactor. This metabolic reactor plays a key role in the catabolism of flavonoids that are not absorbed to break them into simple molecules such as phenolics and aromatic acids.

The intake of carbohydrates as an energy-producing substrate greatly influences blood glucose levels. Other influencing factors may include the type of carbohydrates consumed, the amount of fibre consumed, the method of food preparation, and the level of doneness including the distribution of macronutrients in the entire meal portion. Glycaemic index also contributes to an increase in blood glucose levels. The term is useful when comparing blood glucose levels after consuming carbohydrates in certain amount [12]. Consumption of high-fibre foods also provides a general overview about the glycaemic index. The concept will be different when compared to the use of non-caloric sweeteners in the context of a hypocaloric diet. The recommendation for daily sugar intake is less than 50 grams. The American Heart Association even recommends sugar consumption to be $<100 \mathrm{kcal}$ per day for women and $<150 \mathrm{kcal}$ per day for men; and WHO in 2011 provides a clear limit for sugar intake of $<10 \%$ of the total energy [13].

Our study used two preparations: yogurt and marmalade. Based on Table 1, the group given red dragon fruit peel yogurt (P3) had the lowest weight gain compared to the hypercholesterolemia group (P2) and the group given red dragon fruit peel marmalade (P4). Weight gains in group P2; P3; P4 are $5.40 \pm 1.14$ grams; $26.00 \pm 2.94$ grams; and $32.20 \pm 5.76$ grams, respectively. The protein contained in yogurt will be degraded by proteolytic bacteria when the yogurt enters the digestive system. The whey protein complex in red dragon fruit peel 
yogurt is able to provide a feeling of fullness, therefore it may play a role in weight management. Dairy products such as yogurt contain branched-chain amino acids such as leucine, isoleucine and valine) and lysine which increase their biological value when consumed with whole grains and legumes [14].

Table 1 shows that in the group given yogurt and red dragon fruit peel marmalade, the blood glucose levels decreased by $24.60 \pm 5.77 \mathrm{mg} / \mathrm{dL}$ and $18.66 \pm 2.23 \mathrm{mg} / \mathrm{dL}$, respectively. Flavonoid content in red dragon fruit peel yogurt plays an important role in the process of reducing blood glucose levels. Flavonoids can increase insulin secretion by facilitating glucose transport into cells exposed to free radicals. Glucose will be transferred from the blood to the cells by increasing the permeability of the cell membranes to glucose. The glucose that has entered the cells will be used to produce energy while the remaining glucose will be stored in the liver and muscles as glycogen. Glycogen will act as an energy reserve and can slowly lower blood glucose levels [15]. Anthocyanins in red dragon fruit peel yogurt can reduce blood glucose levels by increasing the sensitivity of insulin receptors and improving antioxidant status by suppressing malondialdehyde (MDA) and increasing levels of superoxide dismutase (SOD) and catalase.

Our study is in line with previous study using red dragon fruit peel filtrate by Laxmi that showed a reduction in blood glucose levels. Pancreatic tissue has a body defence system in the form of endogenous antioxidant enzymes, superoxide dismutase (SOD). The enzymes prevent damage to pancreatic beta cells by catalysing superoxide anions into hydrogen peroxide, which later produce water and oxygen. Triterpenoid content in the peel of red dragon fruit is also able to increase insulin secretion that leads to reduction in blood glucose levels. The mechanism of action of triterpenoids in lowering blood glucose levels is through the activation of GLUT-4. GLUT-4 stimulates translocation to the muscle cell membrane through increased protein kinase (AMPK) activity which allows increased uptake and use of glucose by muscles.

Red dragon fruit peel yogurt is a dairy product that undergoes a fermentation process. The fermentation process in yogurt involves lactic acid bacteria that are commonly known as probiotics. Probiotics are live microorganisms that provide health benefits to the host if consumed sufficiently. The probiotic content in red dragon fruit peel yogurt will play a role in the metabolism of bile salts and produce free peptides. Bile acids are the ingredients needed in the process of absorption of cholesterol molecules from the intestinal lumen. Cholesterol has hydrophobic properties so that bile acids will trigger a form of cholesterol micelle which will then be inhibited through deconjugation in the process of cholesterol absorption. This inhibitory process is crucial in managing hypercholesterolemic conditions. The fermentation process involving lactic acid bacteria such as Lactobacillus bulgaricus and Streptococcus thermophilus will produce short chain fatty acids [15].

Milk fat will undergo biochemical changes during the fermentation process that produces free fatty acids and conjugated linoleic acid (CLA). CLA isomers have a positive effect on hepatic function and glucose metabolism. The isomers also overcome free radicals and are not associated with obesity [14]. 
Table 1. The parameters of experimental rats during the study

\begin{tabular}{lllll}
\hline Parameters tested & $\begin{array}{l}\mathrm{P}^{\mathrm{a}} \\
\text { mean } \pm \mathrm{SD}\end{array}$ & $\begin{array}{l}\mathrm{P}^{\mathrm{b}} \\
\text { mean } \pm \mathrm{SD}\end{array}$ & $\begin{array}{l}\mathrm{P}^{\mathrm{c}} \\
\text { mean } \pm \mathrm{SD}\end{array}$ & $\begin{array}{l}\mathrm{P}^{\mathrm{d}} \\
\text { mean } \pm \mathrm{SD}\end{array}$ \\
\hline Body weight $(\mathrm{g})$ & & & & \\
pre & $204.40 \pm 4.67$ & $197.60 \pm 5.27$ & $199.80 \pm 4.92$ & $204.00 \pm 5.43$ \\
post & $228.60 \pm 5.41$ & $233.00 \pm 4.53$ & $225.80 \pm 7.86$ & $236.20 \pm 2.17$ \\
$\Delta$ & $24.20 \pm 1.30^{\mathrm{b}, \mathrm{d}}$ & $35.40 \pm 1.14^{\mathrm{a}}$ & $26.00 \pm 2.94^{\mathrm{b}}$ & $32.20 \pm 5.76^{\mathrm{a}}$ \\
p $^{*}$ & $0.001^{*}$ & 0.001 & $0.001^{*}$ & $0.001^{*}$ \\
\hline Glucose $(\mathrm{mg} / \mathrm{dL})$ & & & & \\
pre & $60.72 \pm 1.43$ & $150.04 \pm 5.10$ & $150.83 \pm 5.81$ & $159.95 \pm 3.00$ \\
post & $60.99 \pm 1.47$ & $152.70 \pm 5.29$ & $126.23 \pm 3.92$ & $141.29 \pm 1.69$ \\
$\Delta$ & $0.28 \pm 0.55^{\mathrm{c}, \mathrm{d}}$ & $2.66 \pm 1.92^{\mathrm{c}, \mathrm{d}}$ & $-24.60 \pm 5.77^{\mathrm{a}, \mathrm{b}, \mathrm{d}}$ & $-18.66 \pm 2.23^{\mathrm{a}, \mathrm{b}, \mathrm{c}}$ \\
p $^{*}$ & $0.326^{*}$ & 0.036 & $0.001^{*}$ & $0.001^{*}$ \\
\hline
\end{tabular}

*Sampling was done 14 days after induction of hypercholesterolemia and 28 days after the start of treatment; mean $\pm \mathrm{SD}$ for observation mode on five rats in each group

P1: Negative group; P2: Hypercholesterolemic group; P3: Hypercholesterolemic, yogurt $1.8 \mathrm{~g} / \mathrm{kg}$ b.wt./day ; P4: Hypercholesterolemic, marmalade 0.94 g/kg b.wt./day.

$\Delta$ : post intervention-pre intervention

$\mathrm{p}^{*}$; paired t-test, a significant difference $(\mathrm{p}<0.05)$; One-Way ANOVA, where significant, post hoc testing

(least significant difference) was done for intergroup comparisons.

aStatistically significant difference $(\mathrm{p}<0.05)$ when compared with P1.

${ }^{b}$ Statistically significant difference $(\mathrm{p}<0.05)$ when compared with $\mathrm{P} 2$.

${ }^{c}$ Statistically significant difference $(\mathrm{p}<0.05)$ when compared with $\mathrm{P} 3$.

${ }^{\mathrm{d}}$ Statistically significant difference $(\mathrm{p}<0.05)$ when compared with $\mathrm{P} 4$.

Marmalade is a mixed product in gel-texture composed of water, sugar, fruit peel, fruit puree or fruit juice. The fruits are mainly from the citrus group. For every 1000 grams of the mixture will produce 200 grams of marmalade and 75 grams come from fruit endocarp [16]. The ingredients used in the process of making dragon fruit peel marmalade is sucrose and red dragon fruit peel. The high pectin content in the red dragon fruit peel accounts for the marmalade texture (gel-like, non-flowing and soft). The sucrose added will acts both as a sweeteners and a preservative because it suppresses the growth of pathogenic bacteria and maximises the role of pectin, as well as makes the marmalade sparkly [17].

Our finding is also in line with a study conducted by Putriningtyas [9]. Blood glucose levels decreased after marmalade administration due to the flavonoid. The blood glucose levels will reduce by increasing the permeability of the membrane of pancreatic beta cells that triggers insulin secretion. The flavonoid play this role. Insulin is a hormone that regulates blood glucose levels both during fasting and after eating [18]; therefore, insulin can lower blood glucose levels and has an opposite mechanism of action with glucagon. 


\section{Conclusion}

Red dragon fruit peel yogurt reduces blood glucose levels more than red dragon fruit peel marmalade. The management of diabetes is to achieve regulation of blood glucose. The total amount of carbohydrate especially carbohydrate complex and glycemic response must be considered for diabetic.

Acknowledgments. This research was funded by Faculty of Sports Sciences, Universitas Negeri Semarang.

\section{References}

[1] G. Mena-Sánchez, N. Becerra-Tomás, N. Babio, and J. Salas-Salvadó. Dairy product consumption in the prevention of metabolic syndrome: A systematic review and meta-analysis of prospective cohort studies. Adv. Nutr. 2019; 10: S144-S153. doi: 10.1093/advances/nmy083.

[2] M. Fernandez and A. Marette. Potential health benefits of combining yogurt and fruits based on their probiotic. Adv. Nutr. 2017; 8: 155-164. doi: 10.3945/an.115.011114.

[3] A. Cassidy and A. M. Minihane. The role of metabolism (and the microbiome) in defining the clinical efficacy of dietary flavonoids. Am. J. Clin. Nutr. 2017; 105 (1): 10-22. doi: 10.3945/ajen.116.136051.

[4] H. Song, Q. Chu, D. Xu, Y. Xu, and X. Zheng. Purified betacyanins from Hylocereus undatus peel ameliorate obesity and insulin resistance in high-fat-diet-fed mice. J. Agric. Food Chem. 2016; 64 (1): 236-244. doi: 10.1021/acs.jafc.5b05177.

[5] S. Wahdaningsih, E. K. Untari, and Y. Fauziah. Antibakteri fraksi n-heksana kulit Hylocereus polyrhizus terhadap Staphylococcus epidermidis dan Propionibacterium acnes. Pharm. Sci. Res. 2014; 1 (3): 180-193. doi: 10.7454/psr.v1i3.3490.

[6] M. Anandharaj, B. Sivasankari, and R. P. Rani. Effects of probiotics, prebiotics, and synbiotics on hypercholesterolemia: A review. Chinese J. Biol. 2014: 1-7. doi: http://dx.doi.org/10.1155/2014/572754.

[7] Mardiana, I. Budiono, and N. D. Putriningtyas. Comparison of organoleptic, protein, lipid and flavonoid content of commercial starter and isolated culture red dragon fruit peel yogurt. Food Res. 2020: 4 (3): 920-925. doi: https://doi.org/10.26656/fr.2017.4(3).380.

[8] Badan Standarisasi Nasional. SNI Marmalade (SNI 01-4467-1998). Jakarta: Badan Standarisasi Nasional- BSN, 1998.

[9] N. D. Putriningtyas, I. Permatasari, D. Oktaviani, A. S. Raha, and S. Wahyuningsih. Red dragon fruit (Hylocereus spp.) peel marmalade effectively improve blood glucose and lipid profile of hypercholesterolemic wistar rats. Indones. J. Nutr. 2020: 9 (1); 61-67. [Online]. Available: https://ejournal.undip.ac.id/index.php/jgi/.

[10] N. Lourith and M. Kanlayavattanakul. Antioxidant and stability of dragon fruit peel colour. Agro Food Ind. Hi Tech. 2013; 24 (3): 56-58.

[11] B. Jamilah, C. E. Shu, M. Kharidah, M. A. Dzulkifly, and A. Noranizan. Physico-chemical characteristics of red pitaya (Hylocereus polyrhizus) peel. Int. Food Res. J. 2011; 18 (1): 279-286.

[12] ADA. Nutrition Recommendations and Interventions for Diabetes. Diabetes Care. 2008; 31 (supplement 1): S61-S78. doi: 10.2337/dc08-S061.

[13] A. S. París, D. B. Carceller, I. M. Lacleta, and R. A. Gamboa. Sugar and diabetes ; international recommendations. 2013; 28: 72-80, 2013.

[14] C. Gomez-Gallego, M. Gueimonde, and S. Salminen. The role of yogurt in food-based dietary guidelines. Nutr. Rev. 2018; 76 (S1): 29-39. doi: 10.1093/nutrit/nuy059.

[15] S. N. Laxmi, Tjandrakirana, and N. Kuswanti. Pengaruh filtrat kulit buah naga merah (Hylocereus polyrhizus) terhadap kadar glukosa darah mencit (Mus musculus) yang diinduksi glukosa. Lentera Bio. 2017; 6(1):1-5. [Online]. Available: http://ejournal.unesa.ac.id/index.php/lenterabio. 
[16] B. Wolf. Confectionery and Sugar-Based Foods. Elsevier, 2016.

[17] D. A. Smith. Jams and preserves: Methods of Manufacture. Encycl. Food Sci. Nutr. 2003; 34093415. doi: 10.1016/b0-12-227055-x/00660-x.

[18] N. Saji, N. Francis, L. J. Schwarz, C. L. Blanchard, and A. B. Santhakumar. Rice bran derived bioactive compounds modulate risk factors of cardiovascular disease and type 2 diabetes mellitus: An updated review. Nutrients. 2019; 11(11). doi: 10.3390/nu11112736. 